\title{
IFAS Community Development: Enhancing Community Through Social Interaction 1
}

\author{
Mark A. Brennan ${ }^{2}$ \\ This paper is part of a series of discussions on \\ community development. This series will include \\ specialized papers on civic engagement, community \\ action, and other topics important to the development \\ of community.
}

\section{Introduction}

The definition of community presented in this discussion views locality as a place where people live and meet their common daily needs together. Such places are comprehensive networks of individual relationships that meet routine needs and express common interests. However, not all relationships serve to create the sense of connection that characterizes community. It is only through a process of deliberate and focused interactions that diverse segments of local society express their common interests and needs. Community action serves as a catalyst for transforming this interaction into purposive efforts that contribute to the emergence of community (Wilkinson 1991; Luloff and Swanson 1995). This process of interaction culminates in the emergence of community.
Interaction is a pervasive and constant feature of local life that provides substance to its ecological, cultural, organizational, and social psychological aspects (Wilkinson 1991). Interaction among residents increases awareness, allows for new channels of communication, and allows for a host of conditions to emerge that contribute to community and its development. Without such interaction, community could not exist. Purposive interaction with others gives direction to processes of collective action and social participation, and is a source of common identity (Wilkinson 1991).

Interaction among local people facilitates many conditions. It leads to the development of community by increasing awareness and allowing for community action. It is often the case that people are unaware of the problems and issues facing other community residents. We are unaware that our neighbor has lost a job, that their family members have an illness, that outside development interests are planning to exploit human and natural resources, or that fellow residents are in need of social and economic services. By interacting with others in a

1. This document is FCS 9206, of a series of the Department of Family, Youth and Community Sciences, Cooperative Extension Service, Institute of Food and Agricultural Sciences, University of Florida. Publication date: August 2004. Reviewed by M. Swisher, PhD, professor, Cooperative Extension Service, Institute of Food and Agricultural Sciences, University of Florida; and A.E. Luloff, PhD, Professor, Department of Rural Sociology, University of Florida, Gainesville, FL, 32611. Please visit the EDIS website at http://edis.ifas.ufl.edu

2. Mark A. Brennan, PhD, Assistant Professor of Community Development, Department of Family, Youth and Community Sciences, Cooperative Extension Service, Institute of Food and Agricultural Sciences, University of Florida, Gainesville, FL, 32611.

The Institute of Food and Agricultural Sciences (IFAS) is an Equal Employment Opportunity - Affirmative Action Employer authorized to provide research, educational information and other services only to individuals and institutions that function without regard to race, creed, color, religion, age, disability, sex, sexual orientation, marital status, national origin, political opinions or affiliations. For information on obtaining other extension publications, contact your county Cooperative Extension Service office. Florida Cooperative Extension Service / Institute of Food and Agricultural Sciences / University of Florida / Larry R. Arrington, Interim Dean 
variety of settings, we become aware of such conditions. We also become aware of our ability to contribute to efforts to improve their, and our own, quality of life.

It is also the case that people are often unaware of organizations, social groups, and clubs that exist within their communities. Because of this, the activities, functions, and services that these groups provide to local life remain untapped. Local residents can play an important role and significantly enhance the community development process. By participating in community groups and community action efforts, residents can directly contribute to the planning and decision making that shapes local social and economic development.

\section{Interaction as the Key to Community Development}

By focusing on local interaction, a unique community development framework is presented (Luloff and Bridger 2003). This interaction-based perspective focuses on the ways that local people come to understand common needs, and contribute to collective actions designed to meet these needs. While acknowledging the social, economic, and cultural elements that exist as a backdrop for local life, this perspective focuses on the persistent features of local life, namely the social interaction of local people in local settings. People sharing a common territory tend to interact with one another over place relevant matters (Wilkinson 1991). Consequently, interaction at the local level provides the basis for the emergence of community and for designing programs to continue its development.

From an interactional perspective, community development is seen as a dynamic process involving diverse social groups. In all localities, numerous distinct groupings of people are present. Through these groups, people act to achieve various interests and goals. Connecting these diverse individual groups is central to community development. This takes place through the purposive interaction of residents (Figure 1). This interaction allows for the emergence of community, which is an encompassing field that pursues the general interests and needs of the locality (Wilkinson 1991; Luloff and Bridger
2003). Community serves to coordinate and unite individual interactions into focused community wide efforts that benefit all residents.

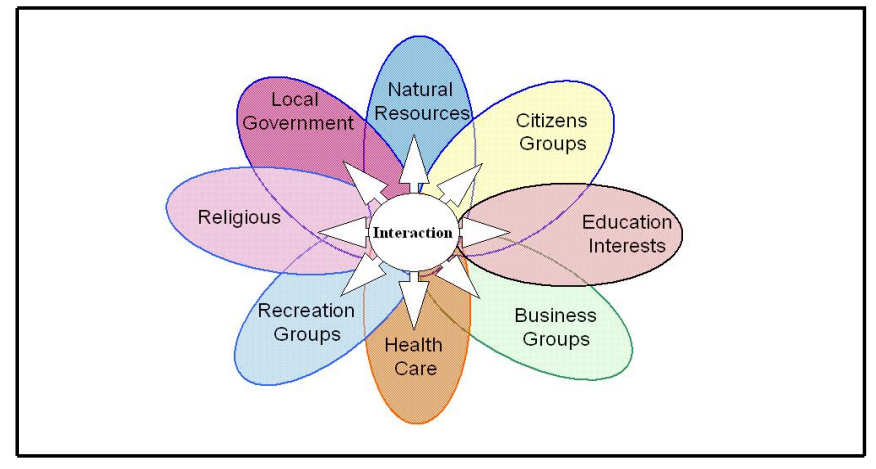

Figure 1.

Community, and the common recognition of needs, cuts across class lines, organized groups, and other entities within a local population. The key component to this process is found in the creation and maintenance of linkages, interaction, and channels of communication among groups that otherwise are directed toward more limited interests (Luloff and Bridger 2003). Through this process, local people are linked more inclusively together and motivated to focus on a wider range of community needs and wants. The relationships that are established and maintained increase the adaptive capacity of people who share a common territory. This adaptive capacity is reflected in the ability of people to manage, utilize, and enhance those resources available to them in addressing local issues (Wilkinson 1991; Luloff and Bridger 2003).

\section{Ways to Foster Interaction}

A variety of conditions can give rise to social interaction, including demographic characteristics such as household size, employment status, educational attainment, and length of residence. As each of these increases, interaction with other residents tends to increase. Generally, all of these conditions expose individuals to more people and provide an arena for them to interact. Social interaction is also facilitated by participation in community based organizations, groups, and voluntary activities. Social groups include cultural, educational, religious, sport, local government, and a variety of other groupings of people. 
To encourage interaction and to contribute to community development, many applied efforts can be developed. Examples include more formally linking organizations and clubs by establishing channels of communication, joint memberships, and co-sponsorship of community events. Additionally, routinely inviting members of other organizations to individual group meetings, the development of community councils that have representatives from multiple groups, and the appointment of representatives from local groups to all major development, government, and other councils would prove useful.

Finally, an important effort can take the form of increasing and enhancing venues of interaction. Such venues can include community centers that are open to all residents, and the promotions of festivals, cultural events, local sport activities, picnics, and religious celebrations. These venues are open to the entire community, bring a variety of diverse individuals together in a social setting, contribute to the local culture and identity, and provide a setting where awareness of diverse issues can take place.

\section{Conclusion}

Efforts to promote, encourage, and support local level interaction should be given priority and actively pursued by community development agents. In facilitating routine and consistent interaction, a basis for community and economic development can be established. Furthermore, by focusing on the extent to which interaction is stifled or inhibited (through policies, social structures, geography, or other conditions), specific steps and efforts can be designed to bring people together.

Community interaction is the single most important component in creating awareness, identifying opportunities to positively contribute, and fostering community action. Through these, more comprehensive programs and planning can be conducted and local decision making enhanced. All contribute to local well-being and enhance local quality of life for our communities.

\section{References}

Luloff, A.E., and J. Bridger. 2003. "Community Agency and Local Development." Pp. 203-213 in, Challenges for Rural America in the Twenty-First Century, edited by D. Brown and L. Swanson. University Park, PA: Pennsylvania State University Press.

Luloff, A. E. and L. Swanson. 1995. "Community Agency and Disaffection: Enhancing Collective Resources." Pp. 351-372 in Investing in People: The Human Capital Needs of Rural America, edited by L. Beaulieu and D. Mulkey. Boulder, CO: Westview Press.

Wilkinson, K. 1991. The Community in Rural America. New York, NY: Greenwood Press. 